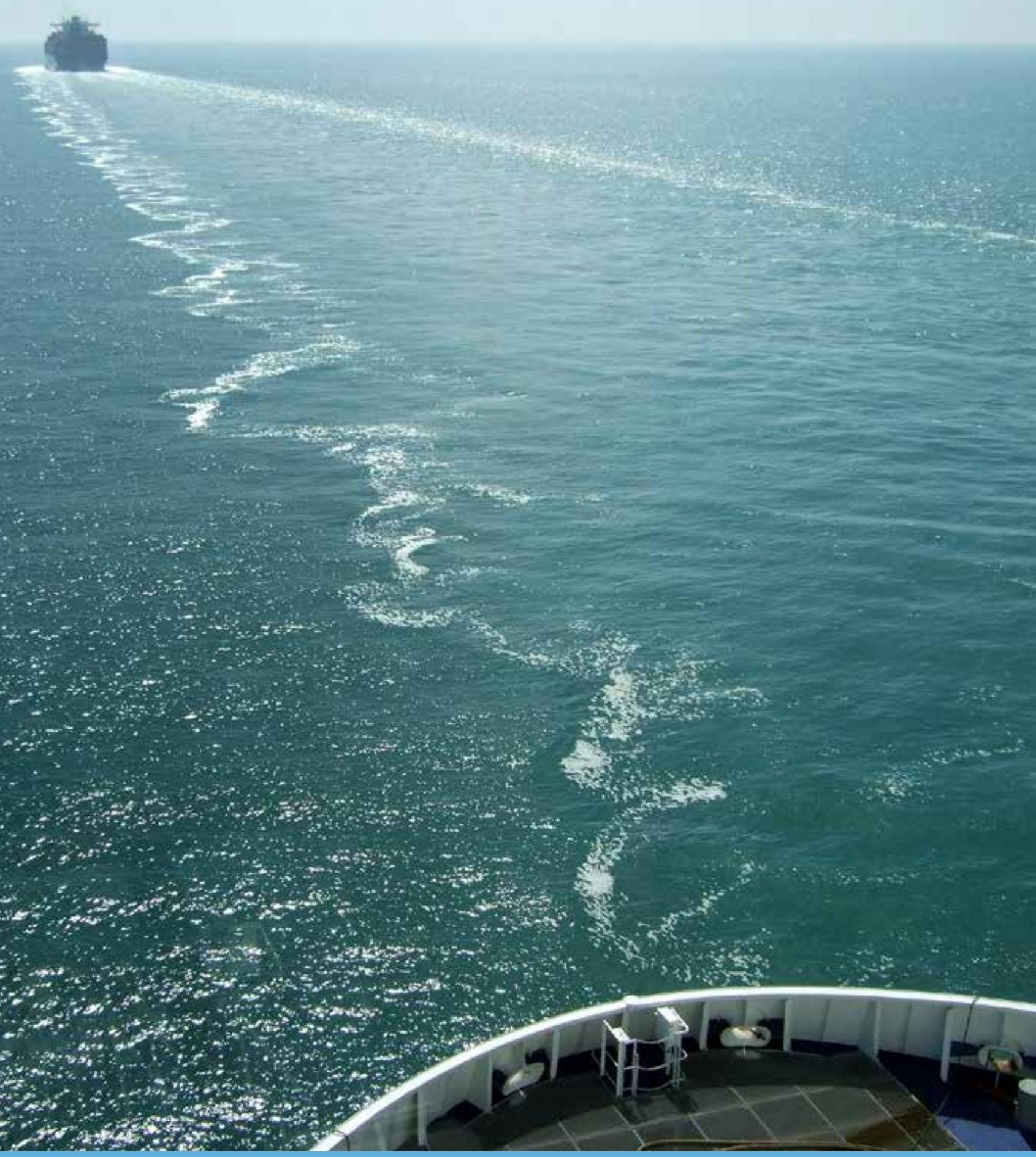

\title{
Review of the implementation of the IMO's 2011 Biofouling Guidelines in the Netherlands
}

W.J. Strietman, E. Leemans 



\section{Review of the implementation of the IMO's 2011 Biofouling Guidelines in the Netherlands}

W.J. Strietman, E. Leemans ${ }^{1}$

1 Leemans Maritime Consultancy

This study was carried out by Wageningen Economic Research and was commissioned and financed by the Dutch Ministry of Infrastructure and Water Management

Wageningen Economic Research

Wageningen, February 2019

REPORT

2019-013

ISBN 978-94-6343-596-3 
Strietman, W.J.; Leemans, E., 2019. Review of the implementation of the IMO's 2011 Biofouling Guidelines in the Netherlands. Wageningen, Wageningen Economic Research, Report 2019-013. 30 pp.; 3 fig.; 0 tab.; 14 ref.

Biofouling (or rather: biological fouling) on ships refers to the process where micro-organisms, plants, algae, or animals accumulate on outside areas of the ship that are (mostly) underwater. Biofouling on ships can result in the transfer of (non-native) invasive aquatic species. This risk has been addressed in the International Maritime Organization's (IMO) 2011 Guidelines for the control and management of ships' biofouling to minimize the transfer of invasive aquatic species (MEPC.207(62)). In this report, the implementation of this guideline in the Netherlands will be reviewed, based on interviews and an online survey.

Biofouling (biologische vervuiling) op schepen verwijst naar het proces waarbij micro-organismen, planten, algen of dieren zich ophopen op de delen van de buitenkant van het schip die (meestal) onder water zijn. Biofouling op schepen kan resulteren in de verspreiding van (niet-inheemse) invasieve aquatische soorten. Dit risico is door de International Maritime Organization's (IMO) geadresseerd in de 2011 Guidelines for the control and management of ships' biofouling to minimize the transfer of invasive aquatic species (MEPC.207(62)). Dit rapport is een review van de implementatie van deze richtlijn in Nederland op basis van interviews en enquêtes.

Key words: shipping, biofouling, IMO, evaluation.

This report can be downloaded for free at https://doi.org/10.18174/470572 or at www.wur.eu/economic-research (under Wageningen Economic Research publications).

(C) 2019 Wageningen Economic Research

P.O. Box 29703, 2502 LS The Hague, The Netherlands, T +31 (0)70 3358330 ,

E communications.ssg@wur.nl, http://www.wur.eu/economic-research. Wageningen Economic Research is part of Wageningen University \& Research.

\section{(cc) BY-NC}

For its reports, Wageningen Economic Research utilises a Creative Commons Attributions 3.0 Netherlands license.

(C) Wageningen Economic Research, part of Stichting Wageningen Research, 2019

The user may reproduce, distribute and share this work and make derivative works from it. Material by third parties which is used in the work and which are subject to intellectual property rights may not be used without prior permission from the relevant third party. The user must attribute the work by stating the name indicated by the author or licensor but may not do this in such a way as to create the impression that the author/licensor endorses the use of the work or the work of the user. The user may not use the work for commercial purposes.

Wageningen Economic Research accepts no liability for any damage resulting from the use of the results of this study or the application of the advice contained in it.

Wageningen Economic Research is ISO 9001:2008 certified.

Wageningen Economic Research Report 2019-013 | Project code 2282200321

Cover photo: Wouter Jan Strietman/Wageningen University \& Research 


\section{Contents}

Summary $\quad 5$

S.1 Summary $\quad 5$

$\begin{array}{lll}\text { S.2 Method } & 6\end{array}$

$\begin{array}{ll}\text { Samenvatting } & 7\end{array}$

$\begin{array}{lll}\text { S.1 Samenvatting } & 7\end{array}$

$\begin{array}{lll}\text { S.2 Methodologie } & 8\end{array}$

1

$\begin{array}{ll}\text { Introduction } & 9\end{array}$

1.1 Introduction $\quad 9$

1.2 Aim 9

$\begin{array}{lll}1.3 \text { Method } & 9\end{array}$

$\begin{array}{ll}\text { Results } & 13\end{array}$

$\begin{array}{lll}3.1 & \text { Introduction } & 13\end{array}$

3.2 Biofouling removal from the hull and niche areas $\quad 13$

Biofouling on the hull and niche areas 13

The current and historical state of biofouling on ships $\quad 15$

Monitoring of measures and their effectiveness $\quad 15$

Costs and benefits related to biofouling measures $\quad 15$

3.3 Application of the 2011 Biofouling Guidelines 16

Awareness of the guidelines $\quad 16$

Clarity of the guidelines $\quad 16$

Experience with the implementation of the guidelines $\quad 16$

Facilities or tools to support the implementation 16

Safety issues relating to the implementation of the guidelines 17

$\begin{array}{lll}3.4 & \text { Inclusion in educational programmes } & 17\end{array}$

3.5 Research and development of technologies or procedures to improve
biofouling management

$\begin{array}{lll}4.1 & \text { Introduction } & 19\end{array}$

4.2 Discussion \& recommendations $\quad 19$

References and websites $\quad 22$

$\begin{array}{lll}\text { Appendix } 1 & \text { In-depth interview questions } & 23\end{array}$

$\begin{array}{lll}\text { Appendix } 2 & \text { Online survey questions (Dutch) } & 25\end{array}$

Appendix 3 Online survey questions (English translation) 27

$\begin{array}{lll}\text { Appendix } 4 & \text { Consulted experts } & 29\end{array}$ 



\section{Summary}

\section{S.1 Summary}

- This review shows that Shipowners and other stakeholders related to the shipping industry in the Netherlands have a basic level of knowledge about the concept of biofouling, its impact (the transfer of invasive aquatic species) and solutions to prevent or remove it from ships.

- In addition, there is also a general awareness of the International Maritime Organization's (IMO) 2011 Guidelines for the control and management of ships' biofouling to minimize the transfer of invasive aquatic species (MEPC.207(62), hereinafter referred to as the 2011 Biofouling Guidelines.

- Based on the interviews and online questionnaire, however, it seems that the main reason for Dutch ship owners to prevent or remove biofouling is not the 2011 Biofouling Guidelines, nor the need to prevent the transfer of invasive aquatic species but rather the need to improve fuel efficiency, since (the accumulation of) biofouling may affect the hydrodynamics of a ship.

- Biofouling measures taken to improve fuel efficiency do have a positive effect in terms of minimising the risk of transferring invasive aquatic species. However, the focus on fuel efficiency means that the main attention for regular biofouling removal and prevention is primarily focused on areas that most affect the hydrodynamics of a ship, such as the hull and propeller(s).

- In terms of monitoring and evaluation, 7 out of 12 respondents register the measures taken, 4 of which also register the effects. The term 'register' was not specified in the questionnaire and the answers might possibly also relate to the registration of fuel efficiency and cost savings. What therefore remains a question is to what extent the measures taken to minimise the transfer of invasive aquatic species are effective in practice.

- Underwater cleaning operations of larger ships usually take place every couple of months, while docked in port. During these operations, the hull (and usually the propeller) are cleaned. Such cleaning services are currently only provided in the larger Dutch ports, mainly due to commercial and practical reasons.

- Niche areas, such as the sea chests and in- or outlets of water cooling systems, are harder to reach during regular cleaning operations. These areas are usually only cleaned during dry-docking, which takes place once every 4-5 years.

- Based on the information collected through the online survey and interviews, it seems likely that both the hull areas and niche areas of ships currently pose a risk in terms of the transfer of (nonnative) invasive species and that current measures do not adequately tackle this risk, especially for the niche areas. It is therefore recommended to assess the situation on site in harbours and drydocks and provide recommendations for future steps.

- Several new technologies to tackle biofouling are either available on the market or in development. Based on the review, it is clear though that there is no one-size-fits-all type of solution for biofouling that is or will be commercially available in the near future. Instead, what currently works best and is recommended for the near future is to apply a combination of existing strategies, where the strategy depends on the area of the ship (e.g. a different strategy for niche areas than for the hull area). 


\section{S.2 Method}

- This review follows the recommended steps and questions mentioned in the IMO guidance document Procedure for evaluation of the guidelines for the control and management of ships'biofouling to minimize the transfer of invasive aquatic species (MEPC.1/Circ.811) (IMO, 2013).

- For the purpose of this review, interviews and an online survey have been carried out. In this way, insight was gained into the extent to which the intended results of the 2011 Guidelines have been realised, including the reasons behind this.

- The in-depth interviews took place with 8 stakeholders in key areas related to biofouling. Appendix 4 provides a list of the consulted stakeholders.

- A link to an online questionnaire was sent out with the help of the Royal Association of Netherlands' Shipowners (KVNR) to their members. A total of 13 respondents (ship owners) filled in the questionnaire, representing a fleet of around 400 ships (one third of all ships represented by KVNR).

- This review did not include any on-site assessment into (the extent of) biofouling on ships to verify the results of the online survey and interviews. Therefore, it cannot be determined for certain whether the results of this review reflect the situation on ships in harbours.

- During the writing this report, a supervisory committee consisting of representatives from the Dutch Ministry of Infrastructure and Water Management and the Royal Association of Netherlands' Shipowners provided feedback and guidance on the strategy and background information on the topic of biofouling. 


\section{Samenvatting}

\section{S.1 Samenvatting}

- Deze review laat zien dat scheepseigenaren en andere stakeholders (gerelateerd aan de scheepvaartindustrie) in Nederland basiskennis hebben over het concept biofouling, de impact daarvan (de overdracht van invasieve soorten) en oplossingen om die te voorkomen of te verwijderen van schepen.

- $\mathrm{Er}$ is ook een algemeen bewustzijn van de International Maritime Organization (IMO) 2011 Guidelines for the control and management of ships' biofouling to minimize the transfer of invasive aquatic species (MEPC.207(62), hierna de 2011 Biofoulingrichtlijnen genoemd.

- Op basis van de interviews en de online vragenlijst lijkt het er echter op dat de belangrijkste reden voor Nederlandse scheepseigenaars om biofouling te voorkomen of te verwijderen niet de 2011 Biofoulingrichtlijnen zijn, noch de noodzaak om de overdracht van invasieve soorten te voorkomen, maar eerder vanwege brandstofefficiëntie, omdat (de accumulatie van) biofouling de hydrodynamica van een schip kan beïnvloeden.

- Biofoulingmaatregelen die gericht zijn op brandstofefficiëntie hebben een positief effect op het minimaliseren van het risico van het overbrengen van invasieve aquatische soorten. De aandacht voor brandstofefficiëntie betekent echter ook dat de focus bij verwijdering en preventie van biofouling ligt bij gebieden die het meest van invloed zijn op de hydrodynamica van een schip, zoals de romp en scheepsschroeven.

- Op het gebied van monitoring en evaluatie registreren 7 van de 12 respondenten de genomen maatregelen, waarvan er 4 ook de effecten daarvan registreren. De term 'registreren' is in de vragenlijst niet nader gespecificeerd en de antwoorden kunnen mogelijk ook betrekking hebben op het registreren van de brandstofefficiëntie en kosten. Het blijft daarom de vraag in hoeverre de genomen maatregelen die de overdracht van invasieve soorten tot een minimum moeten beperken, in de praktijk ook effectief zijn.

- Onderwaterreinigingsactiviteiten van grotere schepen vinden meestal om de paar maanden plaats, als deze in de haven liggen. Tijdens deze activiteit wordt de romp (en meestal de scheepsschroef) schoongemaakt. Dergelijke schoonmaakdiensten worden momenteel alleen aangeboden in de grotere Nederlandse havens, voornamelijk vanwege commerciële en praktische redenen.

- Niche-gebieden, zoals zeekasten en de in- of uitlaten van koelwatersystemen, zijn moeilijker te bereiken tijdens reguliere schoonmaakwerkzaamheden. Deze locaties worden meestal alleen schoongemaakt tijdens het dokken, dat eens in de vier à vijf jaar plaatsvindt.

- Op basis van de informatie die is verzameld via de online enquête en interviews, lijkt het waarschijnlijk dat zowel de scheepsromp als de niche-gebieden van schepen op dit moment een risico vormen voor de overdracht van (niet-inheemse) invasieve soorten en dat de huidige maatregelen dit risico niet adequaat aanpakken, met name met betrekking tot de niche-gebieden. Het wordt daarom aanbevolen om in havens en droogdokken de situatie ter plaatse te beoordelen en aanbevelingen te doen voor vervolgstappen.

- Er zijn verschillende nieuwe technologieën commercieel beschikbaar of in ontwikkeling om biofouling aan te pakken. Op basis van deze review is het echter duidelijk dat er geen 'one size fits all'oplossing is voor biofouling die in de nabije toekomst commercieel verkrijgbaar is of zal zijn. In plaats daarvan is wat momenteel het beste werkt en wordt aanbevolen voor de nabije toekomst, het combineren van bestaande strategieën, waarbij de strategie afhankelijk is van het scheepsonderdeel (waarbij er bijvoorbeeld een andere strategie is voor niche-gebieden als voor de scheepsromp). 


\section{S.2 Methodologie}

- Deze review volgt de aanbevolen stappen en vragen die worden genoemd in het IMO guidance document Procedure for evaluation of the guidelines for the control and management of ships' biofouling to minimize the transfer of invasive aquatic species (MEPC.1/Circ.811) (IMO, 2013).

- Ten behoeve van deze review zijn er interviews en een online enquête uitgevoerd. Op deze manier is inzicht verkregen in de mate waarin de beoogde resultaten van de 2011 Biofouling Richtlijnen zijn gerealiseerd, inclusief de redenen hiervoor.

- De diepte-interviews vonden plaats met 8 stakeholders die activiteiten uitvoeren die verband houden met biofouling. Bijlage 4 bevat een overzicht van deze geraadpleegde personen.

- Een link naar een online vragenlijst werd met de hulp van de Royal Association of Netherlands' Shipowners (KVNR) aan hun leden verstuurd. In totaal 13 respondenten (scheepseigenaren) vulden de vragenlijst in, die ongeveer 400 schepen vertegenwoordigen (een derde van alle schepen vertegenwoordigd door KVNR).

- Deze review omvatte geen onderzoek ter plaatse (in havens of op schepen) naar (de mate van) biofouling op schepen, om de resultaten van de online enquête en interviews te kunnen verifiëren. Daarom kan niet met zekerheid worden vastgesteld of de resultaten van deze review representatief zijn voor de situatie op schepen in Nederlandse havens.

- Tijdens het schrijven van dit rapport heeft een begeleidingscommissie bestaande uit vertegenwoordigers van het Nederlandse Ministerie van Infrastructuur en Waterstaat en de Koninklijke Vereniging van Nederlandse Reders feedback gegeven over de aanpak en achtergrondinformatie gegeven over het thema biofouling. 


\section{Introduction}

\section{$1.1 \quad$ Introduction}

In this chapter, the aim and background of this review will be discussed. The results of the review will be presented in Chapter 2. Chapter 3 provides an overview of the results and recommendations for future steps.

\subsection{Aim}

The aim of this report is to review the implementation in the Netherlands of the International Maritime Organization's (IMO) 2011 Guidelines for the control and management of ships' biofouling to minimize the transfer of invasive aquatic species (MEPC.207(62)) (IMO, 2011), following the Procedure for evaluation of the guidelines for the control and management of ships' biofouling to minimize the transfer of invasive aquatic species (MEPC.1/Circ.811) (IMO, 2013).

\section{$1.3 \quad$ Method}

This review follows the recommended steps and questions mentioned in the IMO guidance document Procedure for evaluation of the guidelines for the control and management of ships' biofouling to minimize the transfer of invasive aquatic species (MEPC.1/Circ.811) (IMO, 2013). In that document, specific questions are suggested to include in a review with stakeholders. Some questions are targeted at specific types of stakeholders while others are more general and targeted at all stakeholders (see Appendix 1).

For the purpose of this review, interviews and an online survey have been carried out. In this way, insight was gained into the extent to which the intended results of the 2011 Guidelines have been realised, including the reasons behind this. This review did not include any on site assessment into (the extent of) biofouling on ships to verify the results of the online survey and interviews. Therefore, it cannot be determined for certain whether the results of this review reflect the situation on ships in harbours.

The in-depth interviews took place with 8 stakeholders in key areas related to biofouling. Appendix 4 provides a list of the consulted stakeholders. The online survey was carried as a questionnaire that was sent out with the help of the Royal Association of Netherlands' Shipowners (KVNR) to their members. A total of 13 respondents (ship owners) filled in the questionnaire, representing a fleet of around 400 ships (approximately one third of all ships represented by KVNR).

In accordance to the procedure for evaluation of the guidelines, the answers to the questions in the questionnaire have been used to review the 2011 Biofouling Guidelines based on the following five performance measures:

1. Awareness and dissemination of the guidelines - Have the guidelines been disseminated to relevant parties and are they aware of the guidelines?

2. Impediments to implementation of the guidelines - Are there any omissions and errors with the guidelines that need to be corrected and/or are appropriate facilities and tools available to effectively implement the guidelines?

3. Application of the guidelines - Is there evidence of use of the guidelines?

4. Change in level of biofouling - Is there evidence of changes in the level of biofouling from in-water or dry-dock inspections and/or data on the net benefits from managing biofouling? 
5. Extent of research and development - What research and technology development, related to the guidelines, is available?

In this report, the results of both the eight in-depth interviews and the online survey that was sent out to members of the Royal Association of Netherlands' Shipowners are summarised and discussed.

During the writing this report, a supervisory committee consisting of representatives from the Dutch Ministry of Infrastructure and Water Management and the Royal Association of Netherlands' Shipowners provided feedback and guidance on the strategy and background information on the topic of biofouling. 


\section{Background}

\section{Biofouling}

Biofouling (or rather: biological fouling) is the name given to the process where microorganisms, plants, algae, or animals accumulate on wetted surfaces. Biofouling has been a problem for ships for as long as humanity has been sailing the oceans, and has been first mentioned by Plutarch somewhere around $100 \mathrm{AD}$ :

'when weeds, ooze, and filth stick upon its sides, the stroke of the ship is more obtuse and weak; and the water, coming upon this clammy matter, doth not so easily part from it; and this is the reason why they usually calk their ships' (Plutarch, 2013).
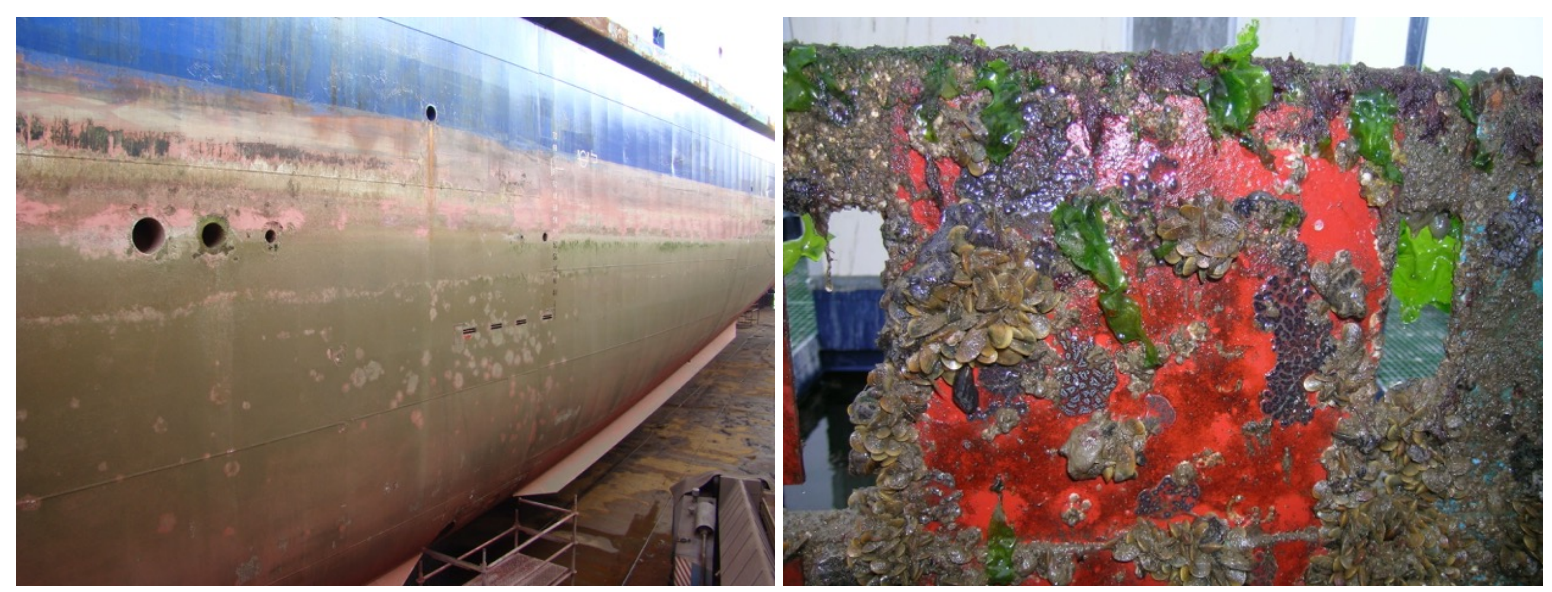

Figure 2.1 Examples of biofouling Source: Endures.

All ships have some degree of biofouling, even those which may have been recently cleaned or had a new application of an anti-fouling coating system. The amount and type of biofouling that may be found on a ship is influenced by a range of factors (IMO, 2011), including the:

1. Design and construction, particularly the number, location and design of niche areas;

2. Specific operating profile, including factors such as operating speeds, ratio of time underway compared with time alongside, moored or at anchor, and where the ship is located when not in use (e.g., open anchorage or estuarine port);

3. Places visited and trading routes; and

4. Maintenance history, including: the type, age and condition of any anti-fouling coating system, installation and operation of anti-fouling systems and dry-docking/slipping and hull cleaning practices.

Implementing practices to control and manage ships' biofouling can greatly assist in reducing the risk of the transfer of invasive aquatic species. Such management practices can also improve a ship's hydrodynamic performance and can be effective tools in enhancing energy efficiency and reducing air emissions from ships (IMO, 2012).

In 2011, the International Maritime Organization (IMO) recognised biofouling as one of the main vectors for the transfer of invasive aquatic species, where the potential transfer and introduction of aquatic invasive species through ships' biofouling threatens the conservation and sustainable use of biological diversity (IMO, 2011). Since biofouling can occur almost any place where water is present, 
biofouling poses not only risks to animal and plant life, it also poses risks to economic and cultural activities (IMO, 2018).

To remove biofouling, the more easy to reach areas for cleaning are the side and bottom of the ship's hull. Areas where biofouling easily accumulates are also referred to as niche areas. These are areas that are more difficult to reach and clean and require different cleaning strategies. Examples of such areas are the sea chest, cooling water inlets, water drainage pipes, the area around the rudder, bowthrusters, the grids at both ends of the bowthruster and propeller(s).

According to a recent study that was carried out in the Netherlands (Gittenberger et al., 2017), seagoing vessels have been identified as the main transport vector to introduce non-native marine species in Dutch waters, including harbours. After introduction, harbours then function as important 'stepping stones' for non-native species along the Dutch coastline and beyond.

\section{The IMO's 2011 Biofouling Guidelines}

The potential for invasive aquatic species transferred through biofouling to cause harm and the need to take measures to prevent this has been recognised by the IMO. Therefore, in 2011 the IMO published Guidelines for the control and management of ships' biofouling to minimize the transfer of invasive aquatic species (resolution MEPC.207(62)), hereinafter referred to as the 2011 Biofouling Guidelines. These guidelines are intended to provide a globally consistent approach to the management of biofouling and to provide useful recommendations on general measures to minimise the risks associated with the transfer and introduction of invasive aquatic species through biofouling for all types of ships.

The 2011 Biofouling Guidelines provide practical guidance on measures to minimise the risk of transferring invasive aquatic species from ships' biofouling to States, ship masters, operators and owners, shipbuilders, ship repair, dry-docking and recycling facilities, ship cleaning and maintenance operators, ship designers, class societies, anti-fouling paint manufacturers and suppliers and any other interested parties.

The 2011 Biofouling Guidelines state that 'as scientific and technological advances are made, the Guidelines will be refined to enable the risk to be more adequately addressed. Port States, flag States, coastal States and other parties that can assist in mitigating the problems associated with biofouling should exercise due diligence to implement the Guidelines to the maximum extent possible.' (IMO, 2011).

Biofouling management measures have also been recognised by the IMO as an effective tool in enhancing energy efficiency and reducing greenhouse gas emissions from ships (resolution MEPC.282(70)) (IMO, 2018).

\section{Review of the IMO's 2011 Biofouling Guidelines in the Netherlands}

Recognising the international risk of biofouling to the marine and coastal environment, the government of the Netherlands supported the decision by the International Maritime Organization during MEPC72 in April 2018, to undertake a review of the Guidelines for the control and management of ships' biofouling to minimize the transfer of invasive aquatic species (resolution MEPC.207(62)) (IMO, 2011).

The accompanying guidance document Procedure for evaluation of the guidelines for the control and management of ships' biofouling to minimize the transfer of invasive aquatic species

(MEPC.1/Circ.811) has been provided by IMO to assist Member States and observers who wish to collect information needed to undertake future reviews of the 2011 Biofouling Guidelines and to do this in a more consistent way. The guidance identifies the types of performance measures that could help to assist in evaluating the different recommendations in the guidelines. 


\section{Results}

\subsection{Introduction}

In this chapter, the results of both the 8 in-depth interviews and the online survey that was sent out to members of the Royal Association of Netherlands' Shipowners are summarised and discussed. The survey has been answered by 13 respondents (representing approximately one third of all members $(1,200$ in total) of the Royal Association of Netherlands' Shipowners) and the interviews were held with stakeholders working for organisations or companies that are related to biofouling: ship owners/operators, maintenance/recycling facility owners and operators, in-water inspection and cleaning service providers, anti-fouling coating experts, port officials, researchers and maritime education institutes.

Although the identities of the stakeholders are known, they are mostly anonymised and the answers have been summarised and combined with those of the online survey.

The sections below are based on the topics related to biofouling mentioned in the Procedure for evaluation of the guidelines for the control and management of ships' biofouling to minimize the transfer of invasive aquatic species (MEPC.1/Circ.811).

\subsection{Biofouling removal from the hull and niche areas}

Biofouling on the hull and niche areas

Biofouling on the hull and in niche areas such as sea chests and seawater piping systems may influence the performance and condition of ships. Biofouling on the hull of a ship may affect hydrodynamics and cause drag and blockages of sea chests and piping may cause engines to run at higher temperatures, potentially resulting in increased fuel consumption and lower performance.

To assess whether the hull and niche areas are cleaned and what the underlying reasons are behind their cleaning strategies, several questions were asked both in the interviews with stakeholders and the online survey of ship owners. All of the persons questioned during the interview and surveyed in the online survey are aware of the concept of biofouling and potential measures to reduce or prevent this. 
In the online survey, ship owners were asked whether their company takes measures to remove biofouling or not, and if they do, if those measures are focused on the hull, niche areas or both. The results show that 2 out of 13 respondents to not take any measures, while 11 out of 13 respondents mention that their company prevents and/or removes biofouling from both areas in one or more of the ways shown in Figure 3.1.

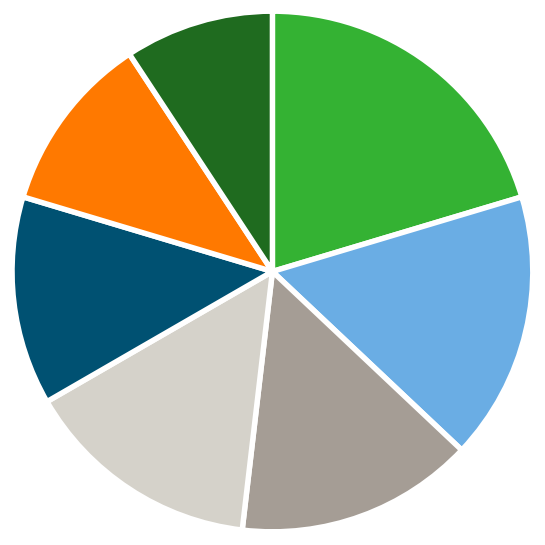

\author{
- Use of antifouling coatings (11) \\ - Cleaning of the propeller (9) \\ - Regular underwater inspections (8) \\ - Cleaning of niche areas (8) \\ - Use of Marine Growth Prevention systems \\ (MGPS)/anti-corrosion systems (7) \\ - Cleaning of the ships' hull the moment that \\ microfouling is detected (6) \\ - Cleaning of the anchor and anchor chains (5)
}

Figure 3.1 Measures taken to remove biofouling a)

a) The numbers correspond with the number of answers in this category where more than one category could be chosen.

Ship owners and other interviewed stakeholders were also asked whether they take specific measures aimed at niche areas. Niche areas may experience substantial growth, making biofouling reduction in these areas a particular challenge. Five out of 13 of the survey respondents mentioned that they do not take any specific measures, while eight out of 13 mentioned that they do. Examples of such measures for niche areas included:

- Bow thruster and grids covering the thruster tunnel: regular antifouling or silicone coating is the best option available in order to reduce the amount of fouling in the thruster tunnels and on the grids covering these tunnels.

- Sea chests: according to those interviewed, Marine Growth Prevention Systems (MGPS) seem to be the most effective way to reduce fouling in sea chests and cooling and seawater piping. MGPS is an active system utilising copper anodes. The system generates copper ions by electrolysis in seawater, these ions will flow through the system creating an environment which prevents micro-organisms from settling (Cathodic Marine Engineering PTE LTD, 2018). Another option for sea chests that was mentioned is to deploy techniques also used in ballast water treatment systems, e.g. UV or using chlorine from seawater. Some companies use self-polishing antifouling in sea chests, but the effectiveness seems to be low. Adjusting the basic design of sea chest might be an option when building new ships.

- Propeller: in principle, propellers are not coated, since growth is usually not a problem and inspection of the propeller is more difficult when coated.

- Rudders are usually coated with regular antifouling paint, but since the flow of water around the rudder is slightly different than that for the hull, a different type of antifouling paint could be applied on the rudder.

- Carrying out a survey on invasive marine species (as required when entering Australian waters).

- Inspection and removal of fouling in niche areas during drydock maintenance. 


\section{The current and historical state of biofouling on ships}

Interviewees were asked whether they have observed a change over time in the amount of biofouling on submerged hull surfaces. In general, no specific rise or decline has been observed. In some cases an increase in biofouling was reported, for which a reason could be the use of (less toxic) anti-fouling paints that require more cleaning of the hull, which is not always adhered to. Also mentioned was that there might not have been a change in the amount of biofouling, but in the type of biofouling, possibly due to the use of different coatings which affect different types of species and organisms.

\section{Monitoring of measures and their effectiveness}

Ship owners were asked whether the measures taken and carried out are registered and evaluated (monitored). Twelve respondents answered this question, out of which 5 mentioned that the measures taken are neither registered nor evaluated. From the 7 respondents who said they do, 4 register both the measures and their effects. The term 'register' was not specified in the questionnaire and the answers might also relate to the registration of fuel efficiency and cost savings. What consequently remains a question is to what extent the measures taken minimise the transfer of invasive aquatic species are effective in practice.

During the interview, a suggested improvement to current registration procedures was to include hull fouling maintenance activities in the regular (digital) maintenance plan, together with all other maintenance information as some port authorities demand a specific paper biofouling record book. Additionally, some say that the port authorities could make inquiries with the ships' Class Society for specific information, as they are entitled to do so. Every ship has to be certified by a Class Society (such as Lloyds Register or DNVGL) on various aspects, covering e.g. safety and environmental issues. The information thus gathered can be obtained online by authorities. Still, some authorities demand specific paper documents.

In this way, it will become more clear to what extent measures are taken and carried out.

\section{Costs and benefits related to biofouling measures}

During the in-depth interviews it became clear that information on costs related to fuel efficiency (and indirectly biofouling) may be registered and analysed by ship owners for the purpose of economic performance analysis, but is usually not shared publicly due to competitive reasons. Another aspect that might be analysed is the manoeuvrability of a ship, which may be affected by fouling, in particular when the propellers are covered in biofouling. Concerns about the potential introduction of alien species into non-native ecosystems seem to be less of a concern and not the primary reason for Shipowners to implement the recommended measures, mentioned in the 2011 Biofouling Guidelines.

According to ship owners that filled in the online questionnaire, the main reason to take measures is to save on fuel costs. Another important reason mentioned are biofouling regulations in specific countries such as New Zealand (Ministry for Primary Industries, 2018). A third reason is to prevent problems relating to seawater cooling (cooling systems may get clogged up with or blocked by biofouling). 


\subsection{Application of the 2011 Biofouling Guidelines}

Awareness of the guidelines

All of those surveyed and interviewed were asked whether they are aware of the 2011 Biofouling Guidelines. Almost all answered that they are aware of the guidelines in general. Only a few are aware of the specific contents of the guideline.

The Government of the Netherlands has engaged relevant stakeholders and representatives of the shipping industry in expert meetings, both at the time of the development phase of the Guidelines and when they had been implemented. After publication in 2011, stakeholders and representatives have been asked by the Dutch Government to further disseminate the information through their members and network.

For example, the Royal Association of Netherlands' Shipowners has actively disseminated the 2011 Biofouling Guidelines and Guidance Document to its members. Furthermore, the 2011 Biofouling Guidelines have been disseminated through Netherlands Regulatory Framework Maritime (NeRF) (formerly known as EasyRules) a governmental service to inform the shipping industry of new rules and regulations.

\section{Clarity of the guidelines}

According to those interviewed and surveyed, the 2011 Biofouling Guidelines are clear in general, although it is not always clear what should be done specifically to fulfil the guidelines or how management plans should be set up.

\section{Experience with the implementation of the guidelines}

In the in-depth interviews, the question was raised whether there are any feasibility issues, omissions or errors that have meant that the 2011 Biofouling Guidelines are difficult to implement. The following answers were given:

- In the design of ships, niche areas that are difficult to clean cannot always be avoided.

- Many recommendations in the guidelines are obvious but not easy to be implemented, and often costly.

- Having an additional dedicated paper record book to register information on biofouling will add to an already heavy administrative workload for the Ship Staff, even though the requested data are available in other maritime documents such as class/flag certificates and docking reports by class societies (electronic maintenance systems etc.).

\section{Facilities or tools to support the implementation}

In the in-depth interviews, the question was raised to all stakeholders whether there are facilities and/or tools available that can support the implementation of the 2011 Biofouling Guidelines. The following answers were provided:

- By means of the Water Act, the Dutch Government (Rijkswaterstaat) issues permits for in-water cleaning operations (hull and propeller cleaning) in about 200 harbours with access to the sea, under the condition that the biofouling coming from cleaned surfaces is siphoned off directly and collected on site. However, the permit is currently only based on physical and chemical parameters and not on the amount and type of non-native species present in biofouling. Further research is planned into the effects of additionally using UV lighting techniques in cleaning operations.

- The availability of underwater cleaning service providers is currently limited to the larger ports, mainly due to commercial and practical reasons.

- In the Netherlands, two techniques are used by companies offering services to remove biofouling from ships. One particular company uses an underwater robot with high pressure water jets to remove biofouling from ship's hulls. The robot consequently pumps the water with removed fouling to a working barge where the water is filtered. Other underwater cleaning companies use rotating brushes to remove biofouling. 
- Since it is not allowed in the Netherlands to leave organic and inorganic matter in the harbour during cleaning operations, all matter that is removed needs to be pumped straight into a barge, where it is mechanically filtered (and sometimes treated with UV light), separating biofouling from the remaining water.

- Dry dock cleaning usually only takes place every 4-5 years and is currently the most effective way to prevent and remove biofouling in niche areas. Since this is usually only being carried out every 4-5 years, a considerable build-up of biofouling can occur in niche areas.

- A contradiction is experienced between efforts to minimise the negative environmental effects of certain antifouling measures (e.g. TBT antifouling, which is currently forbidden by law), and the effectiveness of such (forbidden) measures in relation to its potential in reducing the risk of introducing invasive species.
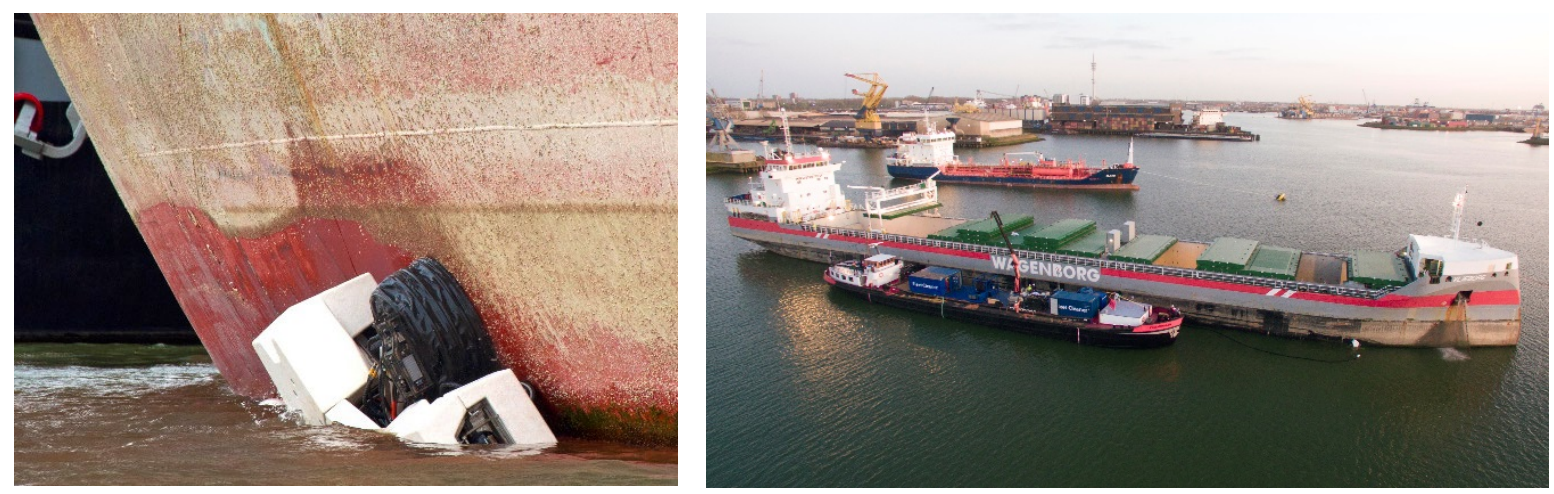

Figure 3.2 Biofouling cleaning using a robot, water jets and a barge to collect biofouling Source: Fleetcleaner.

\section{Safety issues relating to the implementation of the guidelines}

In the in-depth interviews, the question was raised whether any safety issues had been identified in implementing the 2011 Biofouling Guidelines:

- If the inspection/operations to check on the presence or removal of biofouling is carried out by divers, it always involves a safety risk to the divers.

- Another interviewee working at a biofouling removal company mentioned that during loading operations objects may fall from the ship into the water. To prevent damage or injury in case of an object falling during cleaning operations, the company uses equipment that creates a distance between the ship and their barge.

\subsection{Inclusion in educational programmes}

The question whether biofouling and measures to prevent or remove it is included in educational programmes was discussed with an organisation that provides marine environmental courses to professionals in the maritime sector in the Netherlands and abroad. According to ProSea, in the Netherlands, at least some of the Maritime schools have included the issue of biofouling in the curriculum, but not discussing the 2011 Biofouling Guidelines on itself or its specific contents. When it comes to invasive species, the curriculum is mostly focused on ballast water. The issue of biofouling is also part of the IMO Model Course 1.38 for seafarers. 


\subsection{Research and development of technologies or procedures to improve biofouling management}

During the in-depth interviews, the question was raised whether people were aware of new technologies aimed at improving biofouling management, which are either on the market or in the R\&D phase. The following technologies were mentioned:

- A new type of coating using tiny led lights, developed by AkzoNobel and Philps. This innovation integrates UV light-emitting diodes in a protective coating scheme which will allow for the UV light to be emitted from the coating surface, supporting the prevention of biofouling accumulation on the surface of the protected area (AkzoNobel, 2018).

- Some shipping companies deploy a system producing electric currents called MAGIC or Marine AntiGrowth Impressed Current (NME-Group, 2018).

- Ultrasonic technologies.

- Hull Grooming as a preventive cleaning measure, whereby only the first layer of slime is removed in a gentle way. In that way only locally formed biofouling is removed which does not need to be processed and therefore would not need a derogation. This can only be done when the ship has a non-toxic coating and has recently been cleaned.

- Fouling release coatings are often not selected as the primary coating because they are more expensive, but in fact they may be much more effective in reducing fuel use. These type of coatings are usually made with silicone, which is slightly more difficult for marine life to attach to.

- Rotating brushes operated by divers have been in use for some time. The use of high pressure water jets and robots to clean ships' hulls is new though. An example of this new technique is being applied by the company Fleetcleaner, which uses a robot and high power water jets and pumps the removed fouling to a working barge where the water is filtered (Fleetcleaner, 2018). Using water jets provides more control than rotating brushes and could potentially be less damaging to the paint.

- Coatings with microfibers seem to be interesting options but are still in the experimental stage of development.

- HSVA Hamburg is testing a technology to create a layer of air around the ship for active hull fouling control. The technology is called AIRCOAT (Air Induced friction Reducing ship COATing) and consists of a self-adhesive foil system. Applying a ship with such an AIRCOAT foil will produce a thin permanent air layer, which reduces the overall frictional resistance significantly while acting as a physical barrier between water and hull surface inhibiting the attachment of fouling and the release of biocide substances to the water (HSVA, 2018).

- The company Endures BV, involved in antifouling research, has designed a draft plan for a so-called 'Fuel Saving Hull Maintenance Strategy', to be developed in a multi-sponsor or Joint Industry Project, whereby the type of coating and cleaning are adjusted to suit each other. For instance: with a non-toxic coating it is easier to clean the hull in the water (Endures, 2018).

- Small-sized cleaning robots are currently being developed could potentially clean several types of niche areas. This technique has not been tested in the Netherlands yet.

- One of the interviewed shipping companies is ISO 50001 certified, which is focused on Energy Efficiency and whereby biofouling is taken into account. Section 1.5 mentions that 'Implementing practices to control and manage biofouling can greatly assist in reducing the risk of the transfer of invasive aquatic species. Such management practices can also improve a ship's hydrodynamic performance and can be effective tools in enhancing energy efficiency and reducing air emissions from ships'. This concept has also been identified by the IMO in the Guidance for the development of a Ship Energy Efficiency Management Plan (SEEMP) (IMO, 2012). 


\section{$4 \quad$ Discussion and recommendations}

\subsection{Introduction}

The aim of this report has been to review the IMO's 2011 Guidelines for the control and management of ships' biofouling to minimize the transfer of invasive aquatic species (MEPC.207(62)) (IMO, 2011) (hereinafter referred to as the 2011 Biofouling Guidelines), following the Procedure for evaluation of the guidelines for the control and management of ships' biofouling to minimize the transfer of invasive aquatic species (MEPC.1/Circ.811) (IMO, 2013).

In accordance with the procedure for evaluation of the 2011 Biofouling Guidelines, the answers to the questions in the questionnaire have been used to evaluate the implementation and effectiveness of the biofouling guidance based on the following five performance measures:

1. Awareness and dissemination of the guidelines - have the guidelines been disseminated to relevant parties and are they aware of the guidelines?

2. Impediments to implementation of the guidelines - are there any omissions and errors with the guidelines that need to be corrected and/or are appropriate facilities and tools available to effectively implement the guidelines?

3. Application of the guidelines - is there evidence of use of the guidelines?

4. Change in level of biofouling - is there evidence of changes in the level of biofouling from in-water or dry-dock inspections and/or data on the net benefits from managing biofouling?

5. Extent of research and development - what research and technology development, related to the guidelines, is available?

In this chapter, we will discuss the main results of the review. Based on the five performance measures, we will discuss the results and provide recommendations for future steps.

\subsection{Discussion \& recommendations}

\section{Interpretation of the results}

The online survey was carried out in the form of a questionnaire that was sent out to the members (Shipowners) of the Royal Association of Netherlands' Shipowners. A total of 13 respondents (shipowners) filled in the questionnaire. The number of ships owned by these respondents represent approximately one third of all $(1,200)$ ships owned by members of the Royal Association of Netherlands' Shipowners. It is not known whether the answers given and views expressed by these respondents provide a representative view of the remaining two third of these members.

In addition, interviews were carried out with 8 stakeholders in key areas related to biofouling, including several Shipowners. These interviews provided more in-depth information on several key issues related to biofouling and provided a valuable addition to the results of the online survey (which was only directed at Shipowners). Appendix 3 provides a list of the consulted stakeholders.

\section{Awareness of biofouling and dissemination of information about the guidelines}

The results of the interviews as well as the online survey show that there is at least basic knowledge about biofouling and its potential impact, although it is not clear to what extent its environmental risks are fully understood.

The Government of the Netherlands has engaged with the relevant stakeholders in expert meetings and encouraged them to further disseminate the (policy) updates regarding this topic through their 
members and network. During the interviews and online survey, almost all of the respondents answered that they are aware of the guidelines in general, although only a few are aware of the specific contents of the 2011 Biofouling Guidelines. It therefore seems, that the dissemination of information has been successful in terms of raising awareness in general.

Based on the underlying rationale of the 2011 Biofouling Guidelines (reducing the risks associated with biofouling), and the lack of awareness of the specific contents of the guidelines, it is recommended to raise the level of knowledge and urgency around the issue of biofouling and prevention/removal strategies amongst shipping companies, port officials, maintenance suppliers and seafarers. This could be done by, for example:

- Including the topic of biofouling and biofouling prevention/removal in the curriculum of seafarers

- Supplying easy to understand information to shipping companies for use on board

- Organising a seminar on biofouling, inviting a broad range of maritime stakeholders

- Organising a 'side-event' at the IMO, e.g. during a meeting of the Marine Environment Protection Committee

- Suggesting at IMO level to alter the non-mandatory nature of the 2011 Biofouling Guidelines into mandatory guidelines/regulations

\section{Impediments to the implementation of the guidelines}

Based on the interviews and online questionnaire, it seems that when applying strategies to avoid or remove biofouling, the aspects of reduced friction and therefore greater energy efficiency and less fuel consumption seem to be the most important incentives to remove and/or prevent biofouling rather than the potential environmental risks of biofouling or the need to implement the 2011 Biofouling Guidelines.

In other parts of the world, such as New Zealand, legislative requirements mean that measures need to be taken to avoid biofouling. Any vessel that does not meet the requirements is directed to take action to mitigate the risk and, if mitigation measures cannot be taken, is likely to be directed to leave New Zealand waters (Ministry for Primary Industries, 2018). The interviewed stakeholders say that due to that particular local legislation, there is a strong incentive to have the ship cleaned by a certified service provider prior to visiting New Zealand. This also provides a clue as to the potential effect of making regulations on biofouling mandatory in other areas.

\section{Application of the guidelines}

According to those interviewed and surveyed, the 2011 Biofouling Guidelines are clear in general, although it is not always clear what should be done specifically to fulfil the guidelines or how management plans should be set up. Also, many recommendations in the guidelines are said to be obvious but not easy to be implemented, and often costly.

The focus on fuel efficiency means that the main attention for biofouling removal and prevention is focused on the hull and propeller and less on other niche areas such as the sea chests. Since it is known that niche areas, specifically sea chests are both easily overlooked in biofouling removal operations and suitable habitats for a range of marine organisms, these areas need more attention when considering the issue of preventing non-native species to enter marine and coastal ecosystems.

During the in-depth interviews, the question was raised whether there are facilities and/or tools available that can support the implementation of the 2011 Biofouling Guidelines. Those interviewed said that the underwater cleaning industry is in the development phase and not providing services on a large scale yet: underwater cleaning services are limited and only available in the larger ports. It was suggested, that if there would be mandatory guidelines to remove biofouling, then it would also become more attractive from a commercial point of view for cleaning companies to widen their service area.

Some people also mentioned (human) safety concerns related to taking certain measures to prevent or remove biofouling. 


\section{Changes in the level of biofouling}

This review is solely based on in-depth interviews and an online survey. An on-site assessment to determine the extent of biofouling on ships was not part of this review and could therefore not be determined. An on-site assessment has also not taken place around the time when the 2011

Biofouling Guidelines were adopted. Therefore, it is not possible to determine for certain whether the guidelines have been 'implemented to the maximum extent possible' and what its effects have been in terms of minimizing the transfer of invasive aquatic species since its adoption.

Based on the information collected through the survey and interviews, it seems likely that both the hull areas and niche areas of ships currently pose a risk in terms of the transfer of (non-native) invasive species and that current measures do not adequately tackle this risk, especially for the niche areas. It is therefore recommended to assess the situation on site in harbours and dry-docks and provide recommendations for future steps.

\section{Research and Development}

Several new technologies to tackle biofouling are either available on the market or in development. Based on the review, it is clear though, that there is no one-size-fits-all type of solution for biofouling that is or will be commercially available in the near future. Instead, what currently works best and is recommended for the near future is to apply a combination of existing strategies, where the strategy depends on the area of the ship (e.g. a different strategy for niche areas than for the hull area).

Applying new technologies to prevent and remove biofouling can be done most effectively if it is known which type of solution fits which situation or type of vessel the best. This knowledge does not seem to be widely known amongst Shipowners and could be discussed in a new or existing national platform on sustainable shipping. 


\section{References and websites}

AkzoNobel, 2018. AkzoNobel develops pioneering marine fouling prevention solution based on UV-LED technology. Online: https://www.akzonobel.com/en/for-media/media-releases-andfeatures/akzonobel-develops-pioneering-marine-fouling-prevention

Endures, 2018. Overview of our services. Online: https://www.endures.co.uk/services/

Fleetcleaner, 2018. The cleaning installation. Online: https://www.fleetcleaner.com/product/

Gittenberger, A., Wesdorp, K.H. \& M. Rensing, 2017. Biofouling as a transport vector of non-native marine species in the Dutch Delta, along the North Sea coast and in the Wadden Sea. GiMaRIS rapport 2017_09. Online: https://www.nvwa.nl/binaries/nvwa/documenten/dier/dieren-in-denatuur/exoten/risicobeoordelingen/bio-aangroei-als-een-transportvector-voor-uitheemse-soortenin-zuidwest-delta-noordzeekust-en-waddenzee/Bio-

aangroei+als+een+transportvector+voor+uitheemse+soorten+in+Zuidwest+Delta\%2C+Noordzee kust+en+Waddenzee.pdf

HSVA, 2018. AIRCOAT Project Start + Kick-off. Online: https://www.hsva.de/information/newsarchive/newsitems/aircoat-kickoff.html

IMO, 2011. Guidelines for the control and management of ships' biofouling to minimize the transfer of invasive aquatic species. Online:

http://www.imo.org/en/OurWork/Environment/Biofouling/Documents/RESOLUTION\%20MEPC.207 [62].pdf

IMO, 2012. Guidelines for the development of a Ship Energy Efficiency Management Plan (SEEMP). Online: http://www.imo.org/en/KnowledgeCentre/IndexofIMOResolutions/Marine-EnvironmentProtection-Committee-(MEPC)/Documents/MEPC.213(63).pdf

IMO, 2013. Procedure for evaluation of the guidelines for the control and management of ships' biofouling to minimize the transfer of invasive aquatic species. Online:

http://www.imo.org/en/OurWork/Environment/Biofouling/Documents/MEPC.1-Circ.811.pdf

IMO, 2018. Biofouling. Online:

http://www.imo.org/en/OurWork/Environment/Biofouling/Pages/default.aspx

Ministry for Primary Industries, 2018. Biofouling management. Online:

https://www.mpi.govt.nz/importing/border-clearance/vessels/arrival-process-

steps/biofouling/biofouling-management/\#new-biofouling-requirements

MME Group, 2018. MME Impressed Current Anti-Fouling Systems (ICAF). Online: http://www.mmegroup.com/fileadmin/user_upload/Documenten/Downloads/EN/MME-Group-ICAF-Leaflet-English.pdf

Plutarch, 2013. Essays and Miscellanies, The Complete Works Volume 3. Urbana, Illinois: Project Gutenberg. Online: http://www.gutenberg.org/files/3052/3052-h/3052-h.htm

Woods Hole Oceanographic Institute, 1952. "The History and Prevention of Fouling", Marine Fouling and its Prevention (PDF), United States department of the Navy, Bureau of Ships. Online:

https://darchive. mblwhoilibrary.org/bitstream/handle/1912/191/chapter\%2011. pdf?sequence=20

Cathodic Marine Engineering PTE LTD, 2018. Online:https://cathodicme.com/mgps-systems/marinegrowth-prevention-system/ 


\section{Appendix 1 In-depth interview questions}

The following list of questions and corresponding stakeholders was used for the in-depth interviews with stakeholders. The list is based on the document Procedure for evaluation of the guidelines for the control and management of ships' biofouling to minimize the transfer of invasive aquatic species (IMO, 2013).

\begin{tabular}{|c|c|c|}
\hline & Question & Target Group \\
\hline 1 & $\begin{array}{l}\text { Have you disseminated the Guidelines, or communications } \\
\text { based on the Guidelines, to relevant parties including: } \\
\text { Shipowners and operators and shipping agents; } \\
\text { maintenance/recycling facility owners and operators; in- } \\
\text { water inspection and cleaning service providers; ship } \\
\text { designers, naval architects and builders; anti-fouling coating } \\
\text { companies; Harbour Masters; and organizations involved in } \\
\text { maritime/seafarer education and training? }\end{array}$ & Member States. \\
\hline 2 & $\begin{array}{l}\text { Are you aware of the Guidelines? } \\
\text { Is the information in the Guidelines clear? }\end{array}$ & $\begin{array}{l}\text { Shipowners and operators and shipping agents; } \\
\text { maintenance/ recycling facility owners and operators; } \\
\text { in-water inspection and cleaning service providers; } \\
\text { ship designers, naval architects and builders; anti- } \\
\text { fouling coating companies; Harbour Masters; } \\
\text { organizations involved in maritime/seafarer } \\
\text { education and training; recognised organisations. }\end{array}$ \\
\hline 3 & $\begin{array}{l}\text { Are you aware of any information being included in relevant } \\
\text { educational programmes? }\end{array}$ & Member States. \\
\hline 4 & $\begin{array}{l}\text { Have you developed biofouling management measures in } \\
\text { addition to the Guidelines, e.g. national regulations? } \\
\text { Are these measures based on the Guidelines? } \\
\text { Has this additional information been provided to IMO? }\end{array}$ & Member States. \\
\hline 5 & $\begin{array}{l}\text { Are there any feasibility issues, omissions or errors that } \\
\text { have meant that the Guidelines are difficult to implement? }\end{array}$ & $\begin{array}{l}\text { Shipowners and operators; maintenance/recycling } \\
\text { facilities; in-water inspection and cleaning providers; } \\
\text { ship designers, naval architects and builders; } \\
\text { recognised organisations. }\end{array}$ \\
\hline 6 & $\begin{array}{l}\text { Are facilities and/or tools available to support the } \\
\text { implementation of the Guidelines? }\end{array}$ & $\begin{array}{l}\text { Shipowners and operators; maintenance/recycling } \\
\text { facilities; in-water inspection and cleaning providers; } \\
\text { ship designers, naval architects and builders; } \\
\text { recognised organisations. }\end{array}$ \\
\hline 7 & $\begin{array}{l}\text { Have any safety issues been identified in implementing the } \\
\text { Guidelines? }\end{array}$ & $\begin{array}{l}\text { Ship's crew; maintenance and recycling workers; in- } \\
\text { water service providers; and any other entities } \\
\text { directly applying the Guidelines. }\end{array}$ \\
\hline 8 & $\begin{array}{l}\text { Are ships developing biofouling management plans and } \\
\text { maintaining their biofouling record books? }\end{array}$ & Member States; Shipowners and operators. \\
\hline 9 & $\begin{array}{l}\text { Are you undertaking in-water inspections and in-water } \\
\text { cleaning? } \\
\text { Are these activities in line with the Guidelines? }\end{array}$ & $\begin{array}{l}\text { Shipowners and operators and shipping agents; } \\
\text { maintenance/ recycling facility owners and operators; } \\
\text { and in-water inspection and cleaning service } \\
\text { providers. }\end{array}$ \\
\hline 10 & $\begin{array}{l}\text { Does your facility capture hull cleaning waste to minimize } \\
\text { the risk of it entering the water? }\end{array}$ & Maintenance/recycling facility owners and operators. \\
\hline 11 & Do your practices follow, or align with, the Guidelines? & $\begin{array}{l}\text { Shipowners and operators and shipping agents; } \\
\text { maintenance/recycling facility owners and operators; } \\
\text { in-water inspection and cleaning providers; ship } \\
\text { designers, naval architects and builders anti-fouling } \\
\text { coating companies; and organizations involved in } \\
\text { maritime/seafarer education and training. }\end{array}$ \\
\hline
\end{tabular}


12 Is your in-water cleaning technology able to capture most of In-water inspection and cleaning providers. the macrofouling debris from in-water cleaning?

13 Are the submerged hull surfaces of ships as free of Member States; maintenance/ recycling facility biofouling as is feasible?

Have you seen a decrease over time in the amount of owners and operators; anti-fouling coating biofouling on submerged hull surfaces?

14 Are the niche areas and internal seawater cooling systems of Member States; maintenance/ recycling facility ships as free of biofouling as is feasible? owners and operators; anti-fouling coating Have you seen a decrease over time in the amount of companies. biofouling in niche areas and internal seawater cooling systems of ships?

15 Have you collected information about the effectiveness of specific measures in the Guidelines through dry dock

Member States; Shipowners and operators; and inspections of ships?

16 Do you have any information on the direct or indirect Shipowners and operators. benefits associated with implementing with the Guidelines, e.g. reduced fuel consumption as a \% of total operating costs?

17 Do you have any information on the additional costs Member States; and Shipowners and operators. associated with implementing the Guidelines?

18 Are you aware of any research and/or development of Member States; organizations involved in technologies to improve biofouling management? maritime/seafarer education and training; and research organizations.

19 Are you aware of any research into indirect or consequential benefits of implementing the Guidelines?

Member States; organizations involved in maritime/seafarer education and training; and research organizations. 


\section{Appendix 2 Online survey questions (Dutch)}

The following list of questions (in Dutch) was used for the online survey and sent out to the members of the Royal Dutch Shipowners Association and is also based on the 'Procedure for evaluation of the guidelines for the control and management of ships' biofouling to minimise the transfer of invasive aquatic species' (IMO, 2013).

1. Welke functie heeft $u$ binnen uw rederij of organisatie?

2. Was u, voordat u bericht kreeg over deze enquête, bekend met het begrip biofouling?

- Ja

- Nee

3. Bent $u$ bekend met de vrijwillige IMO guidelines uit 2011 'Guidelines for the control and management of ships' biofouling to minimize the transfer of invasive aquatic species' (MEPC.207(62))'?

- Ja, maar alleen dat deze bestaat

- Ja, de inhoud in zijn algemeenheid

- Ja, (grotendeels) de volledige inhoud

- Nee

4. Neemt uw rederij/organisatie maatregelen om biofouling te verwijderen?

- Nee

- Ja, alleen voor de scheepsromp

- Ja, alleen voor de niche plekken (zoals de sea chest, en interne zeewaterkoeling systemen, water afvoerpijpen, ankerkettingen)

- Ja, zowel voor de scheepsromp als voor niche plekken

5. Wat is/zijn voor uw rederij/organisatie de belangrijkste reden(en) om deze maatregelen te nemen? (meerdere antwoorden mogelijk)

- Brandstofbesparing

- Het is in sommige gebieden een verplichting

- Voorkomen dat invasieve soorten ongewild door onze schepen geïntroduceerd worden in wateren waar die niet thuishoren

- Wij volgen de vrijwillige IMO biofouling guidelines

- Anders, namelijk:

6. Welke maatregelen neemt $\mathrm{u}$ om biofouling te voorkomen en/of te verwijderen? (meerdere antwoorden mogelijk)

- Gebruikmaken van antifouling coatings

- Gebruikmaken van Marine Growth Prevention systems (MGPS)/anti-corrosion systems

- Reguliere onderwater inspecties

- Het schoonmaken van de scheepsromp zodra microfouling (slijmlaag) wordt geconstateerd

- Het schoonmaken van het anker en de ankerkettingen

- Het schoonmaken van de scheepsschroef

- Het schoonmaken van niche areas (sea chest, interne zeewaterkoeling systemen en water afvoerpijpen)

- Iets anders, namelijk:

7. Neemt uw rederij/organisatie speciale maatregelen om biofouling in niche gebieden (sea chest, en interne zeewaterkoeling systemen en water afvoerpijpen) te voorkomen en/of te verwijderen?

- Geen speciale maatregelen

- Speciale maatregelen, namelijk 
8. Registreert uw rederij/organisatie welke maatregelen u op het gebied van biofouling uitvoert, waar en wanneer $u$ deze uitvoert/laat uitvoeren en wat daarvan het effect is?

- Ja, we registreren welke maatregelen we toepassen

- Ja, we registreren welke maatregelen we toepassen en waar en wanneer we die uitvoeren

- Ja, we registreren welke maatregelen we toepassen, waar en wanneer we die uitvoeren en wat daarvan het effect is

- Anders, namelijk:

9. Volgt uw rederij/organisatie bij het nemen van maatregelen de adviezen die staan in de vrijwillige IMO biofouling guidelines?

- Nee

- Ja, gedeeltelijk, namelijk:

- Ja, in zijn geheel

10. Is volgens uw rederij/organisatie de informatie en adviezen die in de vrijwillige IMO biofouling guidelines staan duidelijk?

- Ja

- Nee, omdat:

11. Mag Wageningen Economic Research n.a.v. deze enquête contact met u opnemen om eventuele opmerkingen te verduidelijken?

- Ja, mijn e-mail adres is:

- Nee 


\section{Appendix 3 Online survey questions (English translation)}

The following list of questions (translated into English) was used for the online survey and sent out to the members of the Royal Dutch Shipowners Association and is also based on the Procedure for evaluation of the guidelines for the control and management of ships' biofouling to minimize the transfer of invasive aquatic species (IMO, 2013).

1. What is your position?

2. Were you, before you were informed about this survey, aware of the concept of biofouling?

- Yes

- No

3. Are you aware of the non-mandatory 2011 IMO Guidelines for the control and management of ships' biofouling to minimize the transfer of invasive aquatic species (MEPC.207(62))?

- Yes, but only that it exists

- Yes, its general contents

- Yes, (largely) the full contents

- No

4. Does your company/organisation take measures to prevent or remove biofouling?

- No

- Yes, only for the hull

- Yes, only for niche areas (e.g. sea chests, internal seawater cooling systems, water inlets, anchor chains)

- Yes, both the hull and niche areas

5. What are the main reasons for your company/organisation to taken measures (multiple answers possible)

- Fuel efficiency

- It is a legal obligation in some countries

- To prevent invasive species from being unintentionally introduced to waters where they are nonindigenous

- We adhere to the non-mandatory IMO biofouling guidelines

- Other:

6. Which measures are taken to prevent or remove biofouling? (multiple answers possible)

- Use of antifouling coatings

- Use of Marine Growth Prevention systems (MGPS)/anti-corrosion systems

- Regular underwater inspections

- Cleaning of the hull once microfouling (slijmlaag) has been detected

- Cleaning of the anchor and anchor chains

- Cleaning of the propeller

- Cleaning of niche areas (e.g. sea chests, internal seawater cooling systems)

- Other:

7. Does your company/organisation take specific measures to prevent or remove biofouling in niche areas?

- No specific measures

- Specific measures, such as: 
8. Does your company/organisation register which measures relating to biofouling are carried out, where and when and what their effects are?

- Yes, we register which measures we take

- Yes, we register which measures we take, where and when

- Yes, we register which measures we take, where and when and what their effects are

- Other:

9. Does your company/organisation carry out the recommended measures mentioned in the IMO biofouling guidelines?

- No

- Yes, partially, specifically:

- Yes, in its entirety

10. Do you consider the information and recommendations mentioned in the IMO biofouling guidelines to be clear?

- Yes

- No, because:

11. Would you agree if Wageningen Economic Research contacted you to follow up on any specific comments that you might have provided during the survey?

- Yes, my e-mail address is:

- No 


\title{
Appendix 4 Consulted experts
}

\author{
Niels Lyklema \\ Ministry of Infrastructure and Water Management \\ Wouter Rooijakkers \\ Nick Lurkin \\ Arjan Gittenberger \\ Bopp van Dessel / Jerry Lust \\ Cornelis de Vet \\ Jan Tilman \\ Job Klijnstra \\ Marcel van den Broek \\ Ron van Gelder \\ Ministry of Infrastructure and Water Management \\ Royal Association of Netherlands' Shipowners \\ Grimares \\ ProSea \\ Fleetcleaner \\ Van Oord \\ Endures \\ Nautilus \\ Port of Rotterdam \\ Spliethoff
}


Wageningen Economic Research P.O. Box 29703

2502 LS The Hague

The Netherlands

$\mathrm{T}+31(0) 703358330$

E communications.ssg@wur.nl

www.wur.eu/economic-research

Wageningen Economic Research REPORT

2019-013
The mission of Wageningen University \& Research is "To explore the potential of nature to improve the quality of life". Under the banner Wageningen University \& Research, Wageningen University and the specialised research institutes of the Wageningen Research Foundation have joined forces in contributing to finding solutions to important questions in the domain of healthy food and living environment. With its roughly 30 branches, 5,000 employees and 10,000 students, Wageningen University \& Research is one of the leading organisations in its domain. The unique Wageningen approach lies in its integrated approach to issues and the collaboration between different disciplines. 



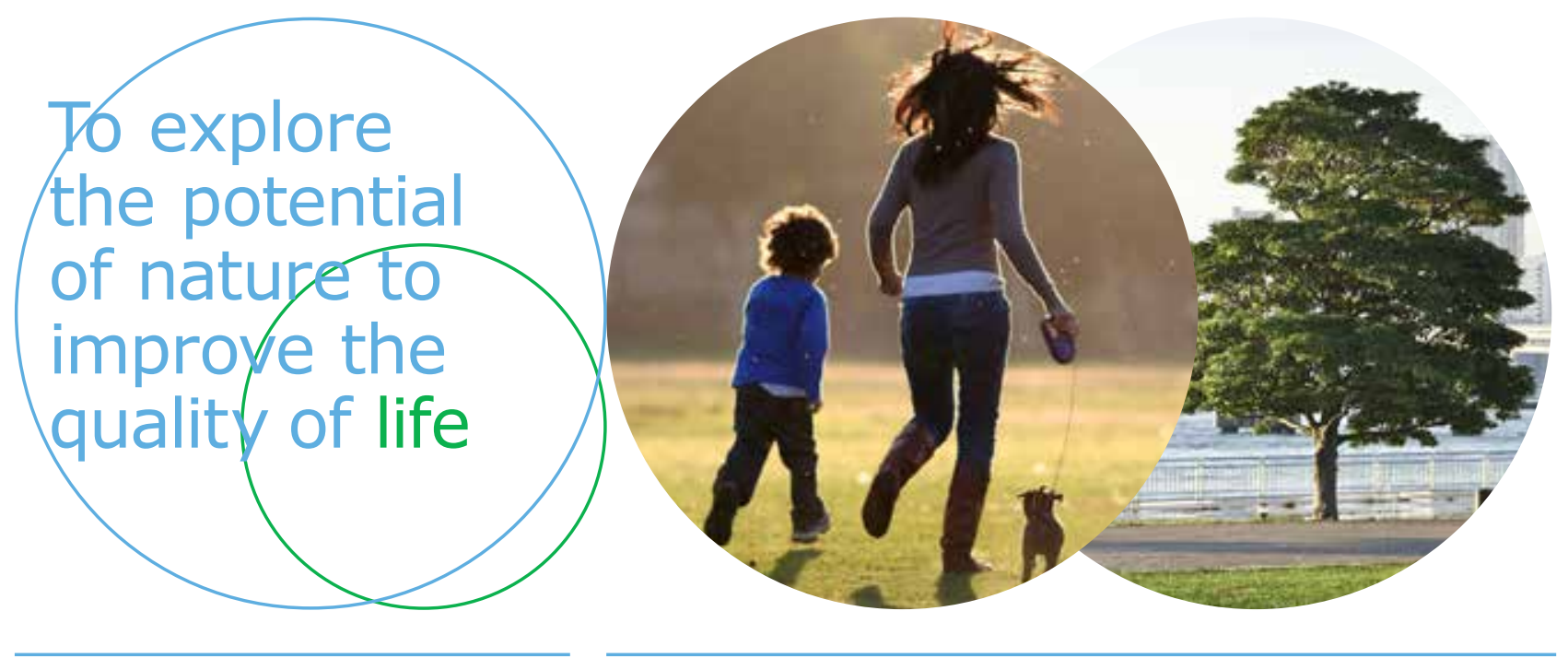

Wageningen Economic Research P.O. Box 29703

2502 LS Den Haag

The Netherlands

E communications.ssg@wur.nl

www.wur.eu/economic-research

Report 2019-013

ISBN 978-94-6343-596-3
The mission of Wageningen University \& Research is "To explore the potential of nature to improve the quality of life". Under the banner Wageningen University \& Research, Wageningen University and the specialised research institutes of the Wageningen Research Foundation have joined forces in contributing to finding solutions to important questions in the domain of healthy food and living environment. With its roughly 30 branches, 5,000 employees and 10,000 students, Wageningen University \& Research is one of the leading organisations in its domain. The unique Wageningen approach lies in its integrated approach to issues and the collaboration between different disciplines. 